\title{
Muscle Characteristics and Meat Quality of Lambs, Grown on Different Nutritional Planes. II. Chemical and Biochemical Effects on Muscle
}

\author{
A. AsGHaR* and N. T. M. Yeates \\ Department of Animal Science, New England University, Armidale, N.S.W., Australia \\ Received June 5, 1978
}

\begin{abstract}
The effect of maintenance (zero-energy balance) and submaintenance (negative-energy balance) feeding, and of subsequent compensatory growth (repletion) on chemical and biochemical aspects of lamb $L$. dorsi muscle were studied. Maintenance and submaintenance feedings were found to cause marked decrease in the contents of lipid, sarcoplasmic proteins and free amino acids nitrogen, while increase in water and stroma proteins (including alkalisoluble and alkali-insoluble stroma fractions) of muscle. Besides the amount, the physicochemical nature of stroma (connective tissue) was also changed by nutritional stress, where by the 'acid-stable' cross-linkages in the structure increased significantly. The myofibrillar proteins, however, decreased only in the case of submaintenance feeding regime.

Almost all the chemical characteristics of muscle from repleted lambs were statistically comparable to those of respective control. However, myofibrillar proteins (on a fat-free, dry weight basis) were slightly less and stroma proteins were slightly high with relatively more 'acid-stable' cross-linkages in muscle from the lambs which experienced compensatory growth. In the light of these results the previous concepts of 'labile proteins reserve' and 'fixed' proteins in muscle have also come under secrutiny.
\end{abstract}

The adverse effects of undernutrition on body components have been reviewed by many workers. McCance ${ }^{(\sim 3)}$ and his associates ${ }^{4,5}$ ) reported a significant decrease in protein content of muscles of monogastric animals (poultry and pig) due to gross undernutrition. Malnutrition has been found to produce similar effect on rat muscle. ${ }^{6}$. No detailed attempts seem to have been made to explore the effect of maintenance and submaintenance feeding on various components of muscle of ruminants which have the ability to recycle endogenous urea under unfavourable conditions. ${ }^{7,8}$;

This paper presents the effect of different degrees of nutritional stress on the chemical and biochemical characteristics of growing lambs' $L$. dorsi muscle, and also examines the concepts of 'labile proteins reserve' and 'fixed' proteins in muscle.

\section{EXPERIMENTAL}

The details of the experimental designs, animal treatments, slaughtering, and relevant statistical meth- ods (applied to determine the number of animal per treatment and analysis of experimental data) have been given in Part $I$ of this series. ${ }^{9}$ The methods used in sampling, handling and preparing the $L$.dorsi muscle for partitioning into different protein fractions, as well as for estimating "swelling factor" of stroma have already been described by Asghar and Yeates. ${ }^{10)}$ Other chemical procedures, such as the determination of water, ash, myoglobin and lipid content, have also been reported elsewhere. ${ }^{11)}$

\section{RESULTS}

The complete results are set out in Tables I and II for expt. i (maintenance) and expt. ii (sub-maintenance and followed by compensatory gain) animals respectively. Only those items which are unusual or of special significance to the stated aims of this part of the total study will receive additional comment. It will be noted in the tables that some of the analytical data are presented both on a fresh and on a fat-free, dry weight basis. The purpose of this was to facilitate understanding of the degree to which differences in muscle composition due to under nutrition are abso- 
Table I. Effect of Maintenance (Zero-energy Balance) Feeding on the Chęical Composition of LAMB $L$. dorsi Muscle

S.D. =standard deviation. The values in parenthesis are based on fat-free, dry weight of muscle, while other are on as such basis, that is on wet weight basis.

\begin{tabular}{|c|c|c|c|}
\hline \multirow[t]{2}{*}{ Muscle components } & Maintenance group & Control group & \multirow{2}{*}{$\begin{array}{l}\text { Statistical } \\
\text { significance } \\
\text { (F. Ratio) }\end{array}$} \\
\hline & Mean \pm S.D. & Mean \pm S.D. & \\
\hline Lipid $(\%)$ & $0.49 \pm 0.37$ & $3.33 \pm 1.08$ & $P<0.001$ \\
\hline Water $(\%)$ & $\begin{array}{l}77.5 \pm 1.09 \\
(351.7)\end{array}$ & $\begin{array}{l}73.4 \pm 1.11 \\
(316.8)\end{array}$ & $\begin{array}{l}P<0.001 \\
P<0.01\end{array}$ \\
\hline Ash $(\%)$ & $\begin{array}{l}1.071 \pm 0.023 \\
(4.873)\end{array}$ & $\begin{array}{l}1.076 \pm 0.021 \\
(4.586)\end{array}$ & $\begin{array}{l}P>0.05 \\
P>0.05\end{array}$ \\
\hline Sarcoplasmic protein $(\%)$ & $\begin{array}{l}5.65 \pm 0.67 \\
(25.58)\end{array}$ & $\begin{array}{l}7.57 \pm 0.72 \\
(32.49)\end{array}$ & $\begin{array}{l}P<0.001 \\
P<0.001\end{array}$ \\
\hline Myofibrillar protein $(\%)$ & $\begin{array}{l}10.01 \pm 0.86 \\
(45.37)\end{array}$ & $\begin{array}{l}9.99 \pm 1.04 \\
(42.99)\end{array}$ & $\begin{array}{l}P>0.05 \\
P>0.05\end{array}$ \\
\hline $\begin{array}{l}\text { Stroma (extra-cellular) } \\
\text { protein }(\%)\end{array}$ & $\begin{array}{l}3.25 \pm 0.40 \\
(14.93)\end{array}$ & $\begin{array}{l}2.24 \pm 0.31 \\
(9.65)\end{array}$ & $\begin{array}{l}P<0.001 \\
P<0.001\end{array}$ \\
\hline $\begin{array}{l}\text { Alkali-soluble fraction } \\
\text { of stroma }(\%)\end{array}$ & $\begin{array}{l}1.12 \pm 0.29 \\
(5.05)\end{array}$ & $\begin{array}{l}0.75 \pm 0.23 \\
(3.22)\end{array}$ & $\begin{array}{l}P<0.05 \\
P<0.01\end{array}$ \\
\hline
\end{tabular}

Table II. Effect of Submaintenance (Negative-energy Balance) Feeding and of Subsequent Compensatory Growth on the Composition of L. dorsi Muscle

The data represent the mean \pm standard deviation. The values carring the same letters for a parameter are not significantly different from one an other $(P>0.05)$. The values in parenthesis are based on fat-free, dry weight of muscle, while the other are on as such basis. Ip=isoelectric point.

\begin{tabular}{|c|c|c|c|c|c|}
\hline Muscle characteristics & $\begin{array}{l}\text { Group I } \\
\text { Datum }\end{array}$ & $\begin{array}{l}\text { Group II } \\
\text { Depleted }\end{array}$ & $\begin{array}{c}\text { Group III } \\
\text { Control }\end{array}$ & $\begin{array}{c}\text { Group IV } \\
\text { Control }\end{array}$ & \\
\hline Water $(\%)$ & $\begin{array}{c}75.0 \pm 0.9^{a} \\
(300,0)\end{array}$ & $\begin{array}{l} \pm 0.7 \\
6.3)\end{array}$ & $\begin{array}{c}75.5 \pm 1.0^{\mathrm{a}} \\
(326.8)^{\mathrm{b}}\end{array}$ & $\begin{array}{l}5.2 \pm 0.6^{\mathrm{a}} \\
323.4)^{\mathrm{b}}\end{array}$ & $.8^{\mathrm{s}}$ \\
\hline Lipid & $.42^{a}$ & 15 & & & \\
\hline Ash & & & 1. & & $: 02^{\mathrm{a}}$ \\
\hline Sarcoplasmi & & 0.35 & $.38^{\mathrm{a}}$ & $40^{\mathrm{a}}$ & $.64^{\mathrm{a}}$ \\
\hline Myoglobin & & & $.07^{\mathrm{a}}$ & & $.04^{\mathrm{a}}$ \\
\hline $\begin{array}{l}\text { Free a } \\
\text { per }\end{array}$ & & 3. & & $37^{\mathrm{a}}$ & \\
\hline Myo & & .36 & & & \\
\hline $\begin{array}{l}\text { Strom } \\
\text { prot }\end{array}$ & & & $\mathrm{a}^{20^{\mathrm{ab}}}$ & $37^{a}$ & \\
\hline Acid- & $01^{\mathrm{a}}$ & & $.03^{\circ}$ & $.05^{\circ}$ & $.04^{b}$ \\
\hline $\begin{array}{r}\text { Alkali } \\
\text { stro }\end{array}$ & & $\begin{array}{l}4.6 \\
(21\end{array}$ & & $38^{b}$ & \\
\hline $\begin{array}{l}\text { Alkali-ir } \\
\text { strom } \\
\text { Acid-sol }\end{array}$ & $12^{\mathrm{a}}$ & 1.16 & $.11^{\mathrm{ab}}$ & $.06^{b}$ & $10^{b}$ \\
\hline $\begin{array}{r}\text { (as } \\
\text { Alka }\end{array}$ & 5 . & & $6.27 \pm 1.1$ & 4.45 & 3 \\
\hline $\begin{array}{l}\text { (a } \\
\text { Alk }\end{array}$ & 87.4 & 106 & $81.8 \pm$ & $82.8 \pm 3.2^{\mathrm{a}}$ & $82.0 \pm 0.4^{a}$ \\
\hline $\begin{array}{l}\text { (as percent of total stroma) } \\
\text { Swelling factor of stroma at Ip }\end{array}$ & $\begin{array}{l}9.01 \pm \\
10.9 \pm\end{array}$ & $\begin{array}{l}19.6 \pm \\
13.3 \pm\end{array}$ & $\begin{array}{l}14.5 \pm \\
11.7 \pm\end{array}$ & $\begin{array}{l}14.0 \pm \\
10.4 \pm\end{array}$ & $\begin{array}{l}14.4 \pm 2.2^{\mathrm{a}} \\
10.6 \pm 1.6^{\mathrm{a}}\end{array}$ \\
\hline & $40.9 \pm 3.8^{\mathrm{b}}$ & $34.8 \pm 1.7^{\mathrm{c}}$ & $40.1 \pm 3.6^{b}$ & $33.4 \pm 1.5^{\circ}$ & $31.9 \pm 2.7^{\circ}$ \\
\hline
\end{tabular}


lute or relative, i.e., in the latter case merely those of fluctuation of water and lipid content, as proposed, for example, by Terreine et al. ${ }^{12}$ )

A. Effect of zero-(maintenance) and negativeenergy balance (sub-maintenance) feeding on muscle components

1. Water and lipid content. Tables I and II show that lipid content of muscle was significantly reduced while water content increased both by maintenance and sub-maintenace feeding $(P<0.001)$. The percentage of lipid was markedly lower and water content significantly higher in the muscle from group II than in groups I and III, but the latter two groups did not differ from each other.

The diminution of lipids from muscle was not surprising in view of the accepted fact that they serve as a source of energy during the period of caloric deficiency. ${ }^{1,2)}$ It is, howerver, interesting to note that some lipid persisted in the muscle from lambs which were maintained at zero- and negative-energy balances. Earlier Masoro et al. ${ }^{13\rangle}$ made similar observations and held that some lipids of the muscle are structurally functional elements which are not catabolized for the purpose of energy in the event of limited caloric supply.

The increase in percentage of water from $75 \%$ to $78 \%$ caused by undernutrition was probably due to over-hydration of the muscle cells. The wasting of cellular tissue leaves space for the accumulation of fluid. To quote McCance"1) "If fat or muscle atrophies inside a rigid framework, replacement with a watery phase is inevitable." Similar views have been expressed by other workers ${ }^{15,16)}$ who investigated the effect of malnutrition on muscle.

2. Ash content. The ash content on a fresh weight basis did not vary due to nutritional state of the lambs, although it tended to be higher in group I than in group II $(0.05<P<0.1)$ and group III $(P<0.05)$. However, on a fat-free dry weight basis (Table I) a non-significant increase in the ash content of muscle due to maintenance feeding did reach significance $(P<0.05)$ under sub-maintenance feeding (Table II). This apparent increase in the ash content of muscle from underfed lambs may be attributed to an increase in sodium ions in the extracellular fluid $^{15 \sim 17)}$ and to an increase in chloride ions. ${ }^{18 \text {; }}$

3. Myoglobin and free amino nitrogen. The myoglobin content was little affected by sub-maintenance feeding (Table II) whereas the free amino nitrogen in the muscle from the underfed group II was significantly lower, both on wet and fat-free dry weight basis, than that from the control group III $(P<0.05)$ and group I $(P<0.001)$. There was no real difference between group III and I. Other workers have reported similar findings on the non-protein nitrogen fraction of muscle from birds, ${ }^{4}$ pigs $^{5}$ and rats. ${ }^{6)}$

4. Sarcoplasmic and myofibrillar proteins. While the sarcoplasmic proteins were significantly reduced both by the maintenance and sub-maintenance feeding $(P<0.001)$, myofibrillar fraction decreased only in the case of latter feeding region. The amount of these proteins was markedly less in the underfed group II as compared to the control group III (Table II) as well as datum line group I $(P<$ 0.05 ), but there was no difference between groups III and I. The relative reduction in sarcoplasmic proteins in the muscle from undernourished lambs might be explained either by a decline in the synthesis of muscle sarcoplasm or by an increase in the catabolism of its constituent proteins. The results on the reduction of sarcoplasmic protein agree with the findings of Dickerson and McCances) on avian muscle and of Yamaguchi and Kanda$\mathrm{tsu}^{\left.6^{2}\right)}$ on rat muscle.

Contrary to the present results McCance and co-workers ${ }^{4,18}$ ) have observed an adverse effect on the myofibrillar proteins of muscle of pigs and cockerels with maintenance feeding. This discrepancy may be explained by the fact that ruminants have the ability to maintain their nitrogen balance by recycling urea $^{7,81}$ at an increased rate when the supply of crude protein in the feed is very low. This may explain as to why maintenance feeding did not decrease the amount of myofibrillar protein in lambs' muscle. 
It is of interest to note that the sarcoplasmic protein content did not reduce more than about $2.0 \%$, on a wet weight basis, from muscle under maintenance and sub-maintenance feeding conditions, although it might have been anticipated that the latter feeding regime would have had a more severe effect on them. The sarcoplasmic fraction contains many kinds of enzymes chiefly those concerning with intermediary glycolytic metabolis $\mathrm{m}^{19}$ ) in muscle syncytia, and are vital for functioning of the cells. That is, probably, why sarcoplasmic proteins were not reduced beyond a certain critical level in spite of the great demand for energy under chronic nutritional stress. Perhaps the amount $(2.0 \%)$ which was lost through nutritional stress represents 'labile proteins reserve.'

The muscle composition of a lamb from group II (No. 239), which lost weight to the point where it could hardly stand on its feet, and was omitted from group comparison, is

\section{Table III. The Muscle Characteristics of a LAMB No. 239 From SubMaINTENANCE Feeding Group II IN Extremely Dystrophic State}

\begin{tabular}{|c|c|c|}
\hline Muscle characteristics & $\begin{array}{l}\text { Wet weight } \\
\text { basis }\end{array}$ & $\begin{array}{c}\text { Dry weight } \\
\text { basis }\end{array}$ \\
\hline Water $(\%)$ & 81.50 & - \\
\hline Lipid $(\%)$ & - & - \\
\hline Sarcoplasmic protein $(\%)$ & 5.81 & 30.87 \\
\hline Myofibrillar protein (\%) & 5.06 & 27.35 \\
\hline $\begin{array}{l}\text { Total stroma protein }(\%) \\
\text { a. Acid-soluble }\end{array}$ & 6.25 & 33.73 \\
\hline $\begin{array}{l}\text { fraction } \\
\text { b. Alkali-soluble }\end{array}$ & 0.17 & 0.92 \\
\hline $\begin{array}{l}\text { fraction } \\
\text { c. Alkali-insoluble }\end{array}$ & 4.43 & 23.94 \\
\hline fraction $(\%)$ & 1.58 & 8.54 \\
\hline Swelling factor of stroma & 28.7 & -- \\
\hline
\end{tabular}

given in Table III. It is interesting to note than in this lamb sarcoplasmic proteins were less by about $2 \%$ that the control group III, while the myofibrillar proteins were lower by $4 \%$. The water content was higher by $6 \%$ as compared to the control group III. This reinforces the suggestion made above that sarcoplasmic proteins are probably not affected beyond a certain critial limit, and that a drastic reduction in the myofibrillar proteins may occur only under chronic nutritional depletion.

5. Stroma (extra-cellular proteins). The relative amount of extra-cellular proteins (stroma) was higher in the muscle from the lambs, kept on maintenance (Table I) or submaintenance feeding (Table II) than from control lambs $(P<0.001)$. The difference was even greater on a fat-free, dry matter basis. The proportion of stroma was also signifcantly greater in muscle from group II than group I.

These results support earlier reports that the proportion of extra-cellular proteins (stroma) in muscle increases following nutritional stress., 18,20 22) In general, muscular dystrophy has been shown to produce a similar effect. ${ }^{23}$ ) It therefore appears that at least muscle collagen and elastin are relatively inert proteins. These data also suggest that conclusions drawn from the determination of total nitrogen alone would provide an uncertain guide to the loss of muscle proteins due to nutritional stress, because the effect is opposite on particular nitrogen fractions of muscle.

It is also obvious that group I animals ( $8 \sim 9$ weeks old) contained a significantly $(P<0.05)$ higher amount of stroma than group III (15 weeks old). This indicated a relative reduction in the proportion of extracellular proteins in the muscle of normally growing lambs with advancing age. Wilson ${ }^{20}$ observed a similar effect of age on the collagen and elastin content of muscle from cattle, but some workers have reported otherwise. ${ }^{21,24)}$

6. Sub-fractions of stroma. The data on alkali-insoluble, alkali-soluble and acid-soluble fractions of extra-cellular proteins (stroma) of different groups are shown in the tables. It can be seen that on wet and fat-free, dry weight basis, the alkali-insoluble fraction of stroma in muscle significantly increased by maintenance feeding $(P<0.05)$. Submaintenance feeding caused similar effect both on alkali-insoluble and alkali-soluble fractions. 
The muscle from group II contained relatively more of these fractions than from groups III and I. The difference was even more pronounced on a fat-free, dry weight basis. The acid soluble fraction, the so-called procollagen generally did not vary significantly between groups except that of underfed group II. When these fractions were expressed as percentage of the total stroma in muscle the effect of undernutrition was again apparent on the fractions.

The comparison between groups I, III and IV indicates that initially the proportion of alkali-soluble fraction tends to decrease and alkali-insoluble fraction increases with age (up to the age of 9 weeks), and thereafter their percentages tend to become constant (in this case after the age of 15 weeks). There was least change in the proportion of acid-soluble fraction with age. These results suggest that change in stroma fractions was not merely a reflection of undernutrition but also of age. Hence, it can be proposed that only the proportions of alkali-soluble and insoluble fractions of stroma in the muscle change with variation in the nutritional status and age of the animals. Significant difference in any of these stroma fractions (on a weight basis) was not merely due to variation in the total amount of stroma of muscle from different groups of lambs.

7. Swelling factor. This factor signifies the extent of cross-linkages; low value of swelling factor represents relatively numerous cross-linkages, and vica versa. ${ }^{9}$ ) The results in Table II indicate that the swelling factor of extra-cellular proteins of muscle from control lambs (group III) was greater $(P<0.05)$ than those which suffered nutritional stress (group II). The group II animals had lower values than those of group I $(P<0.05)$, but groups I and III did not differ significantly from each other.

Figure 1 illustrates visually the structural differences in the interstitial connective tissues of the muscle from well fed group III and from underfed group II animals. The connective tissues from the control lambs appeared as smooth fine fibrils. On treatment with $0.1 \mathrm{M}$ acetic, they underwent pronounced swelling resulting in a very soft gel (Fig. 1a). In the case of undernourished lambs, connective tissues were more compact, coarse and dense. These differences are indicative of subtle conformational changes in the molecular structure of collagen, due to the formation of crosslinkages. Thus the difference in the swelling factor suggests that the intra-muscular collagen from underfed lambs had relatively more 'acid-stable' cross-linkages, and that from the control lambs more 'acid-labile' cross-linkages. Such differences in the collagen structure possibly explains the progressive decrease in the value of swelling factor of connective tissues as a consequence of nutritional stress.

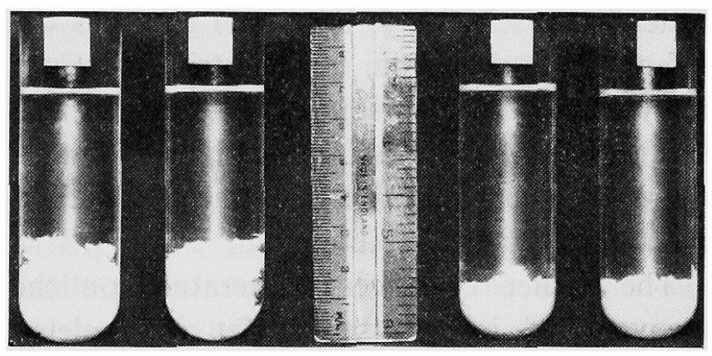

Fig. 1. Extra-cellular Protein (Stroma) per Unit Weight of Longissimus dorsi Muscle from a Depleted Lamb, Group II (Left Pair) and from a Control Lamb, Group III (Right Pair) in $0.1 \mathrm{M} \mathrm{KCl}$ in $0.005 \mathrm{M}$ Phosphate Buffer at $\mathrm{pH}$ Value 7.0.

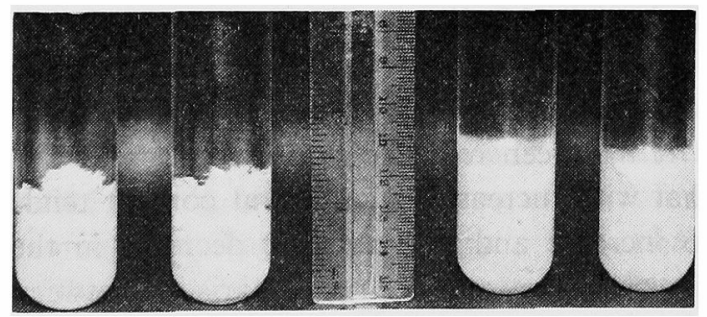

FIG. 1a. Extra-cellular Protein (Stroma) per Unit Weight of Longissimus dorsi Muscle from a Depleted Lamb (the Same as of Fig. 1), Group II (Left Pair) and from a Control Lamb, Group III (Right Pair) in $0.1 \mathrm{~m}$ Acetic Acid.

The difference in structural features of these stroma is very well pronounced.

\section{B. Effect of compensatory growth (repletion)} on muscle composition

Table II shows that the difference in the 
mean values of water, lipid, ash, free amino acid nitrogen and sarcoplasmic protein, and the proportion of different fractions of stroma in muscle from rehabilitated lambs (group V) and the corresponding control group IV was not statistically significant $(P>0.05)$. However, the content of water, ash and stroma decreased while that of lipid, free amino acid nitrogen and sarcoplasmic protein increased significantly in the muscle from repleted lambs during compensatory growth as compared to the muscle from depleted group II. This indicated that the amount of these components in muscle from underfed lambs returned to normal after restoring them on to an adequate nutrition.

The work of Waterlow and Mendes ${ }^{17}$ ) on children also showed that the proportion of water in muscle fell to a normal range as the infants recovered from undernutrition. Contrary to this, Widdowson et al..$^{5}$ reported that the muscle of pigs that suffered from undernutrition contained more extracellular fluid even after being rehabilitated.

The earlier evidence in literature on the recovery of intra-muscular fat in repleted animals is rather conflicting. Callow, ${ }^{25}$ ) and Hill $^{26)}$ found no difference in the intra-muscular fat between recovered and control animals, while others ${ }^{27,28}$ indicated that the replenished animals were lacking in 'marbling.' It is likely that this divergence rests upon variation in the length of the recovery period and age of animal.

It has been reported by many workers ${ }^{29 \sim 32}$ ) that with increasing age the fat content tends to increase and the moisture decrease in the muscle. However the comparison between groups I, III and IV (Table II) does not show any significant change in the percentage of water and lipid content of muscle with the age of lambs (between 8 to 30 weeks).

On the other hand, there were still some differences in the myofibrillar protein content (on wet basis) between repleted group $\mathrm{V}$ and the control group IV (Table II) though the means were not statistically different $(P>$ 0.05). On a fat-free dry weight basis the former had a lower percentage of these proteins than the latter $(P<0.05)$. When com pared with depleted group II the myofibrillar proteins increased significantly $(P<0,05)$ in the muscle from group $\mathrm{V}$ after a periodlof compensatory growth. This again indicatedra substantial recovery of the proportion of myofibrillar proteins in muscle in response to adequate feeding. In general, the proportion of these proteins in muscle tended to increase with advance in age of the lambs.

The total stroma (extra-cellular proteins) and the alkali-soluble fraction content of stroma, were higher in the muscle from lambs which experienced compensatory growth (group V) than in those from control group IV $(P<0.05)$. This observation is compatible with the proposition that collagen, once deposited in the inter-cellular space, becomes metabolically inert and is degraded, if at all, only slowly. ${ }^{1)}$ This inertness, however, may not be absolute, since collagen behaves differently in different tissues. ${ }^{33,34)}$

Although the swelling factor was lower for group V then for control group IV, the difference was not statistically significant $(P>0.05)$. Figs. 2 and $2 \mathrm{a}$, however, show that the intramuscular connective tissue from group $\mathrm{V}$ was more dense and coarse than that from group IV. This suggests that the changes which occurred in collagen as a result of nutritional stress may be irreversible. The swelling factor also decreased greatly as the age of the lambs increased. This suggests that changes

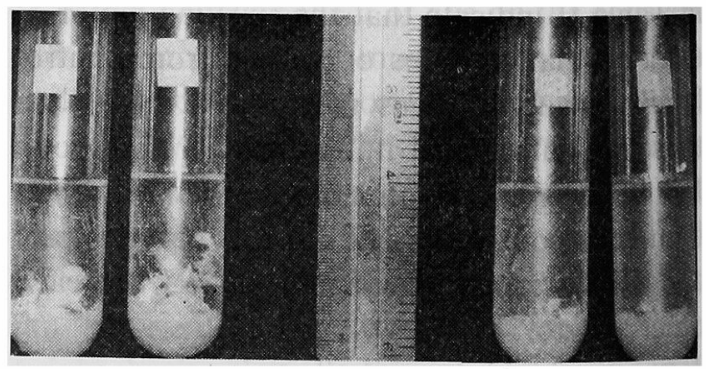

FIG. 2. Extra-cellular Protein (Stroma) per Unit Weight of Longissimus dorsi Muscle from a Repleted Lamb, Group V (Left Pair) and from a Control Lamb, Group IV (Right Pair) in $0.1 \mathrm{M} \mathrm{KCl}$ in $0.005 \mathrm{M}$ Phosphate Buffer at pH Value 7.0. 


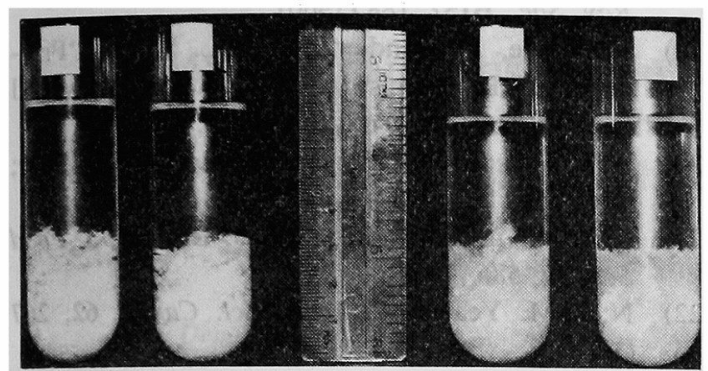

Fig. 2a. Extra-cellular Protein (Stroma) per Unit Weight of Longissimus dorsi Muscle from a Repleted Lamb, Group V (Left Pair) and from a Control Lamb, Group IV (Right Pair) in $0.1 \mathrm{~m}$ Acetic Acid.

The difference in the structural features of stroma is still obvious.

occurred in the molecular structure of collagen with advance in age of the animals, and that these changes were similar to those produced by nutritional stress in the early stage of the growing period of the lambs.

\section{DISCUSSION}

The present study suggests that apart from other factors, the magnitude of the changes in muscle composition also depends on the degree of severity to which energy values of the diet are reduced. It is well documented that an excess of body fat protects the animal against loss of proteins from the body during undernutrition. ${ }^{35,36}$ ) When most of the body fat is lost the nitrogen output rises. This is sometimes referred to as 'premortal' rise and is equated with depletion of fat stores below a certain critical leval necessary to protect body protein. ${ }^{37 \text { ) }}$

On the other hand it is believed that some proteins which accumulate in muscle and other body organs under adequate feeding conditions, are readily catabolized during undernutrition to provide energy and perhaps amino acids for essential functions in the living cells. This has led to the concept of a 'labile proteins reserve' in the body. However, the actual storage forms of such proteins have remained largely unidentified. ${ }^{1 \sim 3)}$ As fat as muscle is concerned, it was not clearly known whether the protein lost (or recycle) during under- feeding represented an overall diminition of fibre substance or the loss was confined to a particular component, such as the sarcoplasmic proteins. The present study shows that tissue lability and its significane is somewhat complicated in muscle- a tissue composed of different types of proteins which responded differently to nutritional stress. The intracellular proteins (sarcoplasmic and myofibrillar) were very sensitive to nutritional deficiency, whereas the extra-cellular proteins were apparently resistant. The collagen, once formed in the inter-cellular space, presumably becomes relatively inert metabolically in muscle.

This suggests that Waterlow's concept ${ }^{38}$ ) of a sharp dividing line between 'fixed' and 'labile' muscle proteins needs some reappraisal. Because, there appears to be two fairly distinct phases of protein loss from muscle when the animals are subjected to nutritional stress of different intensity. Firstly, there is a phase of loss mainly due to disappearance of some sarcoplasmic proteins (possibly the so-called labile proteins reserve) from the muscle cells (syncytia), when the growing animals are kept on maitenance feeding. The remaining sarcoplasmic proteins seem to be independent of maintenance and submaintenence feeding. The duration of this phase may well be a function of the magnitude of fat stores and proteins reserves in muscle. Secondly, there is a phase when myofibrillar proteins of the muscle cells begin to catabolize, and, become the major source of protein loss in the case of submaintenance feeding, continuing so long as the animal remains on that feeding regim. This phase probably represents crucial protein depletion, whereas the initial loss may be more in the nature of a metabolic adaptation (homeostasis mechanisms) of the muscle to the lack of energy supply.

Garrow $^{39,40)}$ postulated that depletion of a subject causes an alteration in the protein synthesis; certain 'essential' protein being favoured at the expence of loss essential ones. This hypothesis may apply in part to muscle proteins, but it is contrary in so far as the 
extra-cellular proteins, which are not as important functionally as the contractile system of actin and myosin, are least affected.

Acknowledgements. Thanks are due to Dr. V. J. Bofinger and Professor E. J. Burr for their advices in the statistical analysis of the experimental data. One of the authers (A. Asghar) was a Commonwealth Interchange Scheme Fellow from Pakistan.

\section{REFERENCES}

1) H. N. Munro, in "Mummalian Protein Metabolism," eds. by H. N. Munro and J. B. Allison, Vol. I, Academic Press, New York, 1964, p. 381.

2) J. C. Waterlow, J. Cravioto and J.M.L. Stephen, Adv. Protein Chem., 15, 131 (1960).

3) L. E. Holt, E. Halac and C. N. Kajdi, J. Am. Med. Assoc, 181, 669 (1962).

4) J. W. T. Dickerson and R. A. McCance, Brit. J. Nutr., 14, 332 (1960).

5) E. M. Widdowson, J. W. T. Dickerson and R. A. McCance, ibid., 14, 457 (1960).

6) M. Yamaguchi and M. Kandatsu, Agric. Biol. Chem., 31, 776 (1967).

7) T. R. Houpt, Am. J. Physiol., 197, 115 (1959).

8) M. R. Cocimano and R. A. Leng, Proc. Aust. Soc. Anim. Prodn., 6, 378 (1966).

9) A. Asghar and N. T. M. Yeates, Agric. Biol. Chem., 43, 429 (1979).

10) A. Asghar and N. T. M. Yeates, ibid., 38, 1851 (1974).

11) A. Asghar and N. T. M. Yeates, J. Sci. Food Agrid., 12, 1 (1977).

12) E. F. Terroine, E. Brenckmann and A. Feuerbach, Archv. Inst. Physiol., 20, 466 (1922).

13) E. J. Masoro, L. B. Rowell, R. M. McDonald and B. Steiert, J. Biol. Chem., 241, 2626 (1966).

14) R. A. McCance, Spec. Rep. Ser. Med. Res. Coun., (British Wuppertal), 1951, No. 275.

15) H. Schnieden, R. G. Hendrick and C. P. Haigh, Trans. R. Soc. Trop. Med. Hyg., 52, 169 (1958).

16) R. Smith, Clin. Sci., 19, 275 (1960).

17) J. C. Waterlow and C. B. Mendes, Nature, Lond., 180, 1361 (1957).

18) E. M. Widdowson and R. A. McCance, Proc.
Roy. Soc., B152, 188 (1960).

19) A. White, P. Handler and E. L. Smith, "Principles of Biochemistry," 5th ed., McGraw-Hill Kogakusha, Ltd., Tokyo, 1973, p. 412.

20) P. M. Wilson, J. Agric. Sci. Camb., 44, 67 (1954); ibid., 45, 1110 (1954).

21) C. W. Kim, G. P. Ho and S. J. Ritchey, J. Food Sci., 32, 586 (1967).

22) N. T. M. Yeates, J. Agric. Sci. Camb., 62, 267 (1964).

23) E. G. Holmes, Q. J. Expt. Physiol. Cogn. Med. Sci., 50, 203 (1965).

24) J. C. Dreyfus, G. Schapira and F. Schapira, J. Clin. Chem., 233, 2653 (1964).

25) E. H. Callow, J. Agric. Sci. Camb., 56, 265 (1961).

26) F. Hill, J. Sci. Food Agric., 18, 164 (1967).

27) W. H. Pfander, Bull. Mo. Agric. Expt. Sta., 1955, No. 652.

28) T. L. J. Lawrence and J. Pearce, J. Agric. Sci. Camb., 63, 23 (1964).

29) E. Post, E. Pelczynske and Pikiclna, Lebensm. Wiss. Technol., 5 (2) (1972).

30) G. Sh. Grigoryan, Zhivotnovodstvo, No. 4, 58 (1974) [Food. Sci. Technol. Abstr., 6, 8S965 (1974)].

31) A. F. Gordienko, Dokl. TSKhA., No. 210, 245 (1975) [Food. Sci. Technol. Abstr., 8, 11 S1976 (1976)].

32) N. N. Kulikova, Dokl. TSKhA, No. 210, 241 (1975) [Food. Sci. Technol. Abstr., 8, 11S1975 (1976)].

33) G. Gerber, G. Gerber and K. I. Altman, J. Biol. Chem., 235, 2653 (1960).

34) K. T. Kao, D. M. Hilker and T. H. McGavack, Proc. Soc. Exp. Biol. Med., 1961, 106, 121, 335.

35) C. M. Young, A. M. Brown, E. L. Empey and D. Turk, J. Nutr., 64, 203 (1958).

36) J. B. Longenecker and H. P. Sarett, Fedn. Proc., 21 (2), 398 (1962).

37) W. H. Chambers, J. P. Chandler and S. B. Baka, J. Biol. Chem., 131. 95 (1939).

38) J. C. Waterlow, in "Protein Metabolism," ed. by F. Goss, Gottingen and Heidelberg, Berlin, 1962, p. 90.

39) J. S. Garrow, in "Amino Acid Malnutrition," ed. by W. H. Cole, Rutgers Univ. Press, New Brunswick, New Jersey, 1957, p. 14.

40) J. S. Garrow, J. Clin. Invest., 38, 1241 (1959). 